\title{
The native cashew tree of Roraima in the experience of Prevfogo in the Indigenous Lands of the "lavrado": to conserve and to use that ancestral wealth in that State whose own name derives from the Karib designation of the cashew - IOROI (Anacardium occidentale L.)
}

\author{
Ari Alfredo Weiduschat ${ }^{1}$ e Joaquim Parimé Pereira Lima ${ }^{2}$
}

${ }^{1} \mathrm{e}^{2}$ : Brazilian Institute of Environment and Renewable Natural Resources.

Ari.weiduschat@ibama.gov.bre Joaquim.lima@ibama.gov.br

\begin{abstract}
The state of Roraima has the largest Amazonian savannah - the "lavrado", of about 61 thousand $\mathrm{km}^{2}$, shared in part with Guyana. The region is inhabited by the Macuxi, Taurepang and Ingaricó ethnic groups (Karib linguistic trunk) and Wapichana (Aruak trunk), distributed in 27 Indigenous Lands. As is well known, savannas have fire as a factor of their own phyto-physiognomic formation. However, current human practices in agriculture and livestock have influenced the increase in fire cases. As they are repeated, the fires weaken the forested areas and provoke a growing savanization in this region and in its surroundings. In the work of Prevfogo / RR are involved six brigades - more than a hundred of brigadistas, selected and coming from the own communities. Over the years, it is remarkable how the use of prescribed burnings and burnings have shown a significant reduction in the need for combat during the most critical periods of the summer. Considering this indicator, the present experience of tree cultivation was carried out as a complementary strategy of MIF, focusing on cashew tree cultivation. The choice of this anacardiaceae was based on a previous study about the pre-Columbian occurrence in the region and its current natural geographic distribution in about 26 agglomerates called "native cajuais". In this "lavrado" environment, the species developed the typical characteristics of the "precocious dwarf cashew", developed by Embrapa in commercial clones from few plantations in the northeastern coast. Thus, the native cashews point out that here is a broad genetic base of this kind, whose conservation is essential for breeding programs. On the other hand, when looking at aspects of the recent history of the indigenous production system and the role of the cashew tree in it, the autonomous adoption of fruit tree plantations is noteworthy. It is urgent to propose initiatives involving research, academia and social organizations to establish action plans that contemplate the possibility of commercial cultivation. Given the vulnerability of the population and the ecosystem in the current reality, the perspective of yields derived from the cashew tree will lead to a new interpretation of the "lavrado", combining the use and conservation of this ancestral wealth. Income, on the other hand, will represent a better life for the families involved.
\end{abstract}

Keywords: 'Lavrado' of Roraima, traditional knowledge of fire, cashew tree. 